\title{
sant
}

http://journal.binadarma.ac.id/index.php/olympia

\section{Analisis Faktor-Faktor Yang Mempengaruhi Mahasiswa Memilih Program Studi Pendidikan Olahraga Universitas Bina Darma}

\author{
Erwanda $^{1}$, M. Haris Satria ${ }^{2}$
}

Universitas Bina Darma Palembang, Indonesia ${ }^{1}$

\begin{tabular}{l}
\hline Info Artikel \\
\hline Sejarah Artikel: \\
Diterima Februari 2019 \\
Disetujui Februari 2019 \\
Dipublikasikan Maret \\
2019
\end{tabular}

Keywords: factors to choose a study program, sports education

\begin{abstract}
Abstrak
Penelitian ini bertujuan untuk mengetahui faktor yang mempengaruhi mahasiswa memilih program studi Pendidikan Olahraga Universitas Bina Darma.Penelitian ini merupakan penelitian deskriptif kuantitatif. Subjek penelitian ini adalah mahasiswa program studi Pendidikan Olahraga Universitas Bina Darma angkatan tahun 2015 sampai dengan 2017 sebanyak 79 responden. Variabel penelitian adalah faktor internal yaitu: minat, motivasi, cita-cita dan faktor eksternal yaitu: keluarga, lingkungan, teman sebaya. Teknik pengumpulan data menggunakan angket sejumlah 69 item pernyataan. Berdasarkan data hasil angket didapatkan mahasiswa yang memilih faktor minat $(62,02 \%)$, faktor motivasi $(15,19 \%)$, faktor cita-cita $(12,66 \%)$, faktor keluarga $(6,33 \%)$, faktor lingkungan $(1,26 \%)$, dan faktor teman sebaya $(2,53 \%)$, sehingga jika ditotal faktor yang paling dominan dipilih adalah faktor minat.
\end{abstract}

\begin{abstract}
This study aims to determine the factors that affect students in choosing courses Sports Education of Bina Darma University. This research is quantitative descriptive. The subjects of this study are students of Sports Education of Bina Darma University class of the year 2015 until class of the year 2017 as many as 79 respondents. Research variable is an internal factor that is: interest, motivation, aspiration and external factor that is: family, environment, peers. Data collection techniques used a questionnaires of 69 statements items. Based on the result of questionnaire data, the students were chosen by the students who chose the interest factor $(62,02 \%)$, motivation factor (15,19\%), aspiration factor (12,66\%), family factor $(6,33 \%)$, environment factor $(1,26 \%)$, and peer factor $(2,53 \%)$, so based on the total of the result that the most dominant factor was selected is a interest factor.
\end{abstract}

\footnotetext{
Alamat korespondensi: Jl. Jend Ahmad Yani No 3 Seberang Ulu 1 Kota Palembang Sumatera Selatan Email: erwandaaaa@gmail.com
} 


\section{PENDAHULUAN}

Perguruan tinggi merupakan jenjang pendidikan akhir yang diselenggarakan untuk menyiapkan peserta didik menjadi anggota masyarakat yang memiliki kemampuan akademik dan profesional yang dapat menerapkan, mengembangkan dan menciptakan ilmu pengetahuan, teknologi dan kesenian.Perguruan tinggi menjadi salah satu sarana dalam penyelenggaraan dan pengembangan pendidikan yang dapat meningkatkan mutu kehidupan masyarakat, bangsa, dan negara (Sunarto dan Agung, 2013: 36). Seiring dengan berkembangnya peradaban, kesadaran akanpentingnya sebuah pendidikan yang baik, bermutu, dan berkualitasjuga semakin dirasakan oleh berbagai kalangan. Para orang tua banyakyang rela merogoh kocek dalam-dalam, hanya agar putra atauputrinya menjadi kaum terdidik, serta memiliki wawasan danpengetahuan yang dapat menjadi bekal mereka dalam mengarungikehidupan.

Masa-masa ketika para peserta didik SMA mencapai titik akhir masa sekolah merupakan suatu keadaan yang sulit. Mereka dihadapkanpada beberapa pilihan, apakah akan memasuki dunia kerja ataumelanjutkan studi ke perguruan tinggi.Saat ini berbagai program pendidikan yang menarik telah banyak ditawarkan oleh banyak perguruan tinggi.Namun, ternyata memilih perguruan tinggi menjadi "kesulitan dan keunikan" tersendiri bagi para calon mahasiswa yang hendak melanjutkan studinya. $\begin{array}{clll}\text { Banyak } & \text { faktor } & \text { yang } & \text { harus } \\ \text { dipertimbangkan } & \text { sebelum } & \text { seorang } & \text { calon }\end{array}$ mahasiswa menentukan pilihannya kepada salah satu program studi pada perguruan tinggi yang diminati. Proses pengambilan keputusan mungkin akan dimulai dengan penetapan tujuan lalu mengembangkan alternatif dan akhirnya menentukan pilihan terbaik. Sebagian orang mungkin akan melakukan pilihan secara spontan tanpa perencanaan, baik karena tergiur oleh promosi, pelayanan, fasilitas gedung dan lainlain tanpa melakukan skala prioritas mana yang lebih dulu dilakukan. Tentu dalam menentukan pilihan kuliah memerlukan proses yang sedapat mungkin objektif, karena akan berakibat jangka panjang dan terkait dengan pengorbanan yang besar, mulai dari waktu, persiapan, dana, dan sikap mental dari mahasiswa tersebut.

Universitas Bina Darma (UBD) merupakan salah satu Perguruan Tinggi di Sumatera Selatan yang juga menawarkan Fakultas Keguruan dan Ilmu Pendidikan (FKIP) sebagai salah satu Fakultas yang ada di dalamnya.FKIP UBD memiliki beberapa pilihan program studi (prodi). Salah satu Prodi yang ada di FKIP UBD adalah Pendidikan Olahraga. Program studi ini bertujuan menghasilkan lulusan yang berkompeten di bidang inovasi olahraga, pendidikan, dan pengajaran olahraga. Pendidikan Olahraga yang ada di FKIP UBD diibaratkan sebagai proses produksi dalam meningkatkan mutu pendidikan di Indonesia.Calon mahasiswa tentu akan memilih jurusan tertentu dengan 
harapan jurusan yang dia pilih nantinya akan dapat menunjang proses pendidikan dikemudian hari dan mendapatkan pekerjaan yang baik. Pada dasarnya Faktor-faktor yang dapat mempengaruhi mahasiswa memilih jurusan pada Perguruan Tinggi sebagai tempat kuliah diantaranya: faktor budaya, faktor sosial, faktor pribadi serta faktor psikologis. Faktor lain yang mempengaaruhi pemilihan jurusan adalah faktor keluarga, individual, pekerjaan, situasi ekonomi, motivasi, persepsi, keyakinan dan sikap serta minat (Jamaris, 2013: 29).

Program studi Pendidikan Olahraga merupakan salah satu program studi yang ditawarkan oleh Universitas Bina Darma.Program studi Pendidikan Olahraga dibuka pada tahun 2008. Minat calon mahasiswa memilih program studi Pendidikan Olahraga Universitas Bina Darma menurun drastis sejak tahun 2014.Menurunnya jumlah mahasiswa ini terjadi karena berbagai faktor. Faktor-faktor inilah yang akan dicari tahu penyebab menurunnya jumlah mahasiswa.

Penelitian ini bermaksud untuk mengetahui faktor dominan yang dapat mempengaruhi mahasiswa dalam memilih Program Studi Pendidikan Olahraga Universitas Bina Darma.Dengan adanya pertimbangan-pertimbangan calon mahasiswa dalam memilih program studi maka penulis tertarik untuk melakukan penelitian lebih lanjut, adapun judulnya adalah sebagai berikut: "Analisis Faktor-Faktor yang Mempengaruhi Mahasiswa Memilih Program
Studi Pendidikan Olahraga Universitas Bina Darma".

Pendidikan tinggi adalah jenjang pendidikan setelah pendidikan menengah yang mencakup program diploma, program sarjana, program magister, program doktor, program profesi, program spesialis, yang diselenggarakan oleh perguruan tinggi berdasarkan kebudayaan bangsa Indonesia (Peraturan Menteri Riset, Teknologi, dan Pendidikan Tinggi Republik Indonesia nomor 44 tahun 2015 tentang Standar Nasional Pendidikan Tinggi).

Menurut Undang-Undang Republik Indonesia nomor 12 tahun 2012 tentang Pendidikan Tinggi Bab IV Pasal 58 ayat (1), Perguruan Tinggi melaksanakan peran sebagai:

1) Wadah pembelajaran Mahasiswa dan Masyarakat

2) Wadah pendidikan calon pemimpin bangsa

3) Pusat pengembangan Ilmu Pengetahuan dan Teknologi

4) Pusat kajian kebajikan dan kekuatan moral untuk mencari dan menemukan kebenaran

5) Pusat pengembangan peradaban bangsa Menurut Undang-Undang Republik Indonesia nomor 12 tahun 2012 tenang Pendidikan Tinggi Bab 1 Pasal 5, Pendidikan Tinggi memiliki tujuan yaitu sebagai berikut:

1. Berkembangnya potensi Mahasiswa agar menjadi manusia yang beriman dan bertakwa kepada Tuhan Yang Maha Esa dan berakhlak mulia, sehat, berilmu, cakap, kreatif, mandiri, 
terampil, kompeten, dan berbudaya untuk kepentingan bangsa

2. Dihasilkannya lulusan yang menguasai cabang Ilmu Pengetahuan dan/atau Teknologi untuk memenuhi kepentingan nasional dan peningkatan daya saing bangsa

3. Dihasilkannya Ilmu Pengetahuan dan Teknologi melalui Penelitian yang memperhatikan dan menerapkan nilai Humaniora agar bermanfaat bagi kemajuan bangsa, serta kemajuan peradaban dan kesejahteraan umat manusia

4. Terwujudnya Pengabdian kepada Masyarakat berbasis penalaran dan karya Penelitian yang bermanfaat dalam memajukan kesejahteraan umum dan mencerdaskan kehidupan bangsa.

\section{Program Studi Pendidikan Olahraga}

Menurut binadarma.ac.id Program Studi Pendidikan Olahraga (PS-POR) Universitas Bina Darma merupakan institusi pendidikan yang menyelenggarakan pendidikan dan pembelajaran terhadap mahasiswastrata satu (S1). Program Studi Pendidikan Olahraga pada awalnya berada di bawah Fakultas Keguruan dan Ilmu Pendidikan. Dengan surat keputusan Menteri Pendidikan dan Kebudayaan SK No. 2024/D/T/2008 tanggal 23 Juni 2008 tentang pembukaan PS-POR.

Sebagai suatu system lembaga pendidikan, PS-POR, penyusunan visinya mengacu pada visi FKIP dan Universitas Bina Darma.Rumusan visi dari PS-POR adalah sebagai berikut "Menjadi pusat pendidikan, pengajaran, pelatihan, penelitian, dan pengabdian kepada masyarakat yang unggul dalam bidang olahraga yang berorientasi pada teknologi informasi, berstandar internasional, dan berbasis karakter bangsa pada tahun 2025".Uraian tentang visi PS-POR sebagai berikut.

1) Pusat Pendidikan dan Pengajaran Merupakan tampat bagi mahasiswa untuk menyiapkan diri menjadi guru professional dalam mata pelajaran Pendidikan Jasmani, Olahraga, dan Kesehatan.

2) Pusat Pelatihan, Merupakan tempat bagi mahasiswa dan pelaku olahraga untuk menyiapkan diri menjadi pelatih dan wasit yang bersertifikat/berlisensi tingkat regional, nasional, dan internasional serta atlet professional.

3) Pusat penelitian, Merupakan tempat bagi dosen dalam mengembangkan kompetensi sebagai ilmuan dalm bidang pendidikan olahraga, khususnya dalam pembelajaran dan kepelatihan.

4) Pusat Penelitian, Merupakan tempatbagi mahasiswa untuk mengembangkan dirinya sebagai calon ilmuan dalam bidang pendidikan olahraga dan kepelatihan.

5) Pusat Pengabdian Kepada Masyarakat, Merupakan tempat bagi dosen dan mahasiswa untuk mendarma baktikan dirinya dalam pengembangan masyarakat sadar akan pentingnya pendidikan olahraga dan pengembangan kompetensi kepelatihan dalam bidang olahraga.Berorientasi pada Teknologi Informasi. 
6) Mempunyai makna manfaatkan teknologi informasi sebagai sarana dalam penyelenggaraan pendidikan, pembelajaran, dilakukan dengan menggunakan ilmu teknologi dan informasi, pemberian tugas secara online dengan menggunakan e-learning, serta penyediaan sarana laboratorium computer dan internet, begitu juga dalam penelitian.

7) Berstandar Internasional, Mempunyai makna kurikulum PS-POR dikembangkan mengacu kepada kompetensi-kompetensi yang berorientasi kepada kebutuhan atau tuntutan global.

8) Berstandar Internasional, Mempunyai makna penyelenggaraan kegiatan keilmuan, misalnya penelitian, seminar, workshop, dan penelitian di kemas sesuai dengan kaidah-kaidah yang berlaku secara global.

9) Berkarakter Bangsa, Dalam menyelenggarakan pendidikan, penelitian, pelatihan, dan pengabdian didasarkan kepada delapan belas (18) nilai-nilai yang terkandung dalam karakter bangsa, yaitu: religious, jujur, toleransi, disiplin, kerja keras, kreatif, mandiri, demokratis, rasa ingin tahu, semangat kebangsaan, cinta tanah air, menghargai prestasi, bersahabat, cinta damai, gemar membaca, peuli lingkungan, peduli social, dan tanggung jawab.

Pengambilan keputusan (decision making) adalah salah satu bentuk perbuatan befikir. Pengambilan keputusan juga merupakan suatu proses pemilihan diantara beberapa alternative yang ada untuk mencapai suatu tujuan yang ditetapkan (Hapsari, 2016: 62). Penentuan keputusan memilih jurusan dalam pendidikan merupakan suatu keputusan yang sangat penting. Tentunya akan banyak sekali pertimbangan-pertimbangan dalam menentukan suatu pilihan. Peserta didik akan dihadapkan terhadap pertanyaan-pertanyaan atas apa yang mereka pilih dan putuskan. Banyak faktor yang akan mempengaruhi peserta didik dalam memilih jurusannya. Ada faktor yang muncul dari dalam.

diri peserta didik tersebut, ada juga faktor yang muncul dari luar peserta didik tersebut. Dalyono (2007:230) berpendapat bahwa proses pengambilan keputusan pemilihan jurusan dapat dipengaruhi oleh dua faktor yaitu faktor internal dan faktor eksternal.

1. Faktor internal
a. Minat
b. Bakat
c. Cita-cita

\section{Faktor eksternal}
a. Keluarga
b. Lingkungan

Tjiptono (2014: 32) menyatakan bahwa "stimulus mempengaruhi kebutuhan seseorang untuk membeli akan produk dan jasa tertentu". Kebutuhan untuk membeli produk atau jasa tersebut dipengaruhi oleh "shortages" (kebutuhan yang timbul karena ketidakpuasan pelanggan terhadap produk dan jasa saat ini). 


\section{METODE PENELITIAN}

\section{Jenis Penelitian}

Penelitian ini merupakan penelitian deskriptif kualitatif. Bentuk penelitian ini didasarkan pada hal yang lebih menekankan pada sifat naturalisme, yaitu realitas yang muncul dan berdasarkan peristiwa-peristiwa nyata yang menjadi bahan kajian penelitian dan data yang terkumpul serta analisisnya bersifat kualitatif.

\section{Sampel}

Sampel penelitian diambil dengan menggunakan teknik purposive sampling. Pada penelitian ini yang menjadi kriteria dalam purposive sampling adalah mahasiswa yang masih aktif mengikuti perkuliahan dan kegiatan kampus yaitu mahasiswa angkatan tahun 2015 sampai angkatan tahun 2017 pada kelas reguler.

\section{Teknik Pengumpulan Data}

Untuk memperoleh data yang sesuai dengan tujuan penelitian, maka perlu dilakukan pengumpulan data secara sistematis.

Dalam mengumpulkan data yang diperlukan peneliti, maka digunakan teknik pengumpulan data angket. Angket ini digunakan untuk mendapatkan data secara objektif tentang faktor-faktor yang mempengaruhi mahasiswa dalam memilih Program Studi Pendidikan Olahraga Universitas Bina Darma baik faktor internal maupun faktor eksternal.

Instrumen angket sebelum digunakan, akan divalidasi terlebih dahulu oleh validator. Validasi instrumen cukup dengan validator karena instrumen yang digunakan adalah instrumen non tes.Angket digunakan untuk menganalisis jawaban-jawaban yang diisi mahasiswa sebagai subjek penelitian.

\section{Analisi Data}

Data dianalisis dengan langkahlangkah sebagai berikut:

1. Memberikan skor pada masing-masing deskriptor yang tampak. Adapun rentang nilai yang ada pada angket sebagai berikut:

Tabel. 3.4 Skala Penilaian

\begin{tabular}{cc}
\hline Skala & Nilai \\
\hline Sangat Setuju & 5 \\
Setuju & 4 \\
Cukup & 3 \\
Tidak Setuju & 2 \\
Sangat Tidak & 1 \\
Setuju & \\
\hline (Sumber: Djahir Basir dan Dwi \\
Hasmidyani, 2015:20)
\end{tabular}

2. Skor kemudian dihitung dengan rumus:

Keterangan:

$$
\mathrm{P}=\frac{F}{N} \times 100 \%
$$

$\mathrm{P}=$ presentase yang dicari untuk setiap jawaban

$\mathrm{F}=$ frekuensi jawaban yang diperoleh

$\mathrm{N}=$ Frekuensi seluruh jawaban $100 \%=$ pembilang tetap.

Validator untuk angket ini adalah Bapak Prof. Waspodo, M.Ed., Ph.D. dan Ibu Dian Rianawati, S.E., M.M. Setelah instrumen divalidasi kepada validator ahli. Maka dilanjutkan dengan uji instrumen angket kepada mahasiswa. Data yang diperoleh tersebut kemudian dicari validitasnya dengan 
cara dihitung menggunakan rumus Product

Moment (Sugiyono, 2016) sebagai berikut:

$$
\mathrm{r}_{x y}=\frac{n \sum x y-\left(\sum x\right) \cdot\left(\sum y\right)}{\sqrt{\left\{n \cdot \Sigma x^{2}-\left(\sum x\right)^{2}\right\} \cdot\left\{n \sum y^{2}-\left(\sum y\right)^{2}\right\}}}
$$

$\mathrm{r}_{x y}=$ Koefisien korelasi antara dua variabel $\mathrm{X}$ dan variabel $\mathrm{Y}$, dua variabe yang dikorelasikan $x=\mathrm{X}-\mathrm{X}$ dan $y=\mathrm{Y}-\mathrm{Y}$

$x y=$ Jumlah perkalian $\mathrm{x}$ dan $\mathrm{y}$

$x^{2}=$ Kuadrat dari $\mathrm{x}$

$y^{2}=$ Kuadrat dari $\mathrm{y}$

Suatu instrumen dikatakan valid jika $r_{\mathrm{xy}}$ lebih dari $r_{\text {tabel. }}$

Kemudian, setelah diperoleh hasil dari validitas instrumen yang akan digunakan dilanjutkan dengan menghitung reliabilitas instrumen tersebut. Reliabilitas yang dicari menggunakan rumus alpha (Arikunto, 2013: 156) yaitu:

$$
R_{11}=\left(\frac{k}{k-1}\right) \cdot\left(1-\frac{\sum S_{i}}{S_{t}}\right)
$$

1. Menghitung varians skor tiap-tiap item sebagai berikut:

$$
\mathrm{S}=\frac{\sum x_{t}^{2}-\frac{\left(\sum x_{t}\right)^{2}}{N}}{N}
$$

2. Menghitung jumlah varians seluruh item:

$$
\sum \mathrm{St}=\mathrm{S} 1+\mathrm{S} 2+\mathrm{S} 3+\ldots+\mathrm{Sn}
$$

3. Menghitung jumlah varians total:

$$
\mathrm{S}=\frac{\sum x_{t}^{2}-\frac{\left(\sum X_{t}\right)^{2}}{N}}{N}
$$

4. Kemudian dihitung dengan rumus alpha

$$
R_{11}=\left(\frac{k}{k-1}\right) .\left(1-\frac{\Sigma S_{i}}{S_{t}}\right)
$$

Kemudian membandingkan hasil dari $r_{11}$ dengan $r_{\text {tabel }}$ dengan $\mathrm{dk}=\mathrm{N}-1$ dengan taraf siginifikansi 5\%, sehingga diperoleh $r_{\text {tabel }}$. Kaidah keputusan: Jika $r_{11}>r_{\text {tabel }}$ berarti reliabel dan jika $r_{11}<r_{\text {tabel }}$ berarti tidak reliabel.
Dalam menganalisis data, peneliti menggunakan teknik analisis data sebagai berikut:

a. Reduksi Data, mereduksi data berarti merangkum, memilih hal-hal yang pokok, memfokuskan pada hal-hal yang penting, dicari tema dan polanya, dengan demikian data yang telah direduksi akan memberikan gambaran yang jelas, dan mempermudah peneliti untuk melakukan pengumpulan data selanjutnya, dan mencarinya bila diperlukan.

b. Penyajian Data (Display), mendisplaykan data berarti mempermudah untuk memahami apa yang terjadi, merencanakan kerja selanjutnya berdasarkan apa yang telah dipahami tersebut.

c. Analisis Data Verifikasi (Conclusion Drawing), langkah terakhir dalam analisis data adalah penarikan kesimpulan dan verifikasi.

\section{HASIL DAN PEMBAHASAN}

Faktor-faktor yang mempengaruhi mahasiswa dalam memilih Program Studi Pendidikan Olahraga Univeritas Bina Darma pada penelitian ini diperoleh melalui angket.

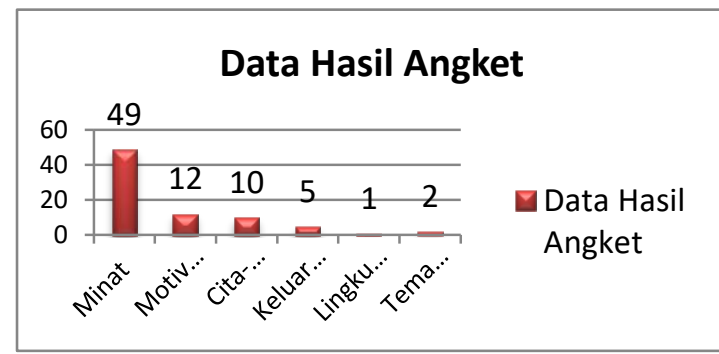

Diagram 1. Faktor yang Mempengaruhi Mahasiswa Memilih Program Studi 
Berdasarkan diagram 1 diatas, terlihat bahwa dari 79 mahasiswa program studi Pendidikan Olahraga Universitas Bina Darma tahun angkatan 2015 sampai dengan 2017 diberikan angket, diperoleh49 mahasiswa memilih faktor minat (62,02\%), 12 mahasiswa memilih faktor motivasi (15,19\%), 10 mahasiswa memilih faktor cita-cita $(12,66 \%)$, 5 mahasiswa memilih faktor keluarga (6,33\%), 1 mahasiswa memilih faktor lingkungan $(1,27 \%)$, dan 2 mahasiswa memilih faktor teman sebaya $(2,53 \%)$.

Berdasarkan data hasil angket mahasiswa didapatkan mahasiswa yang memilih faktor minat $(62,02 \%)$, faktor motivasi $(15,19 \%)$, faktor cita-cita $(12,66 \%)$, faktor keluarga $(6,33 \%)$, faktor lingkungan $(1,26 \%)$, dan faktor teman sebaya $(2,53 \%)$, sehingga jika ditotal faktor yang paling dominan dipilih adalah faktor minat. Mahasiswa yang memilih program studi Pendidikan Olahraga Universitas Bina Darma berdasarkan faktor minat.

\section{Pembahasan}

Faktor-faktor yang mempengaruhi mahasiswa dalam memilih program studi Pendidikan Olahraga Universitas Bina Darma adalah cara bertindak dan berperilaku dalam menentukan pengambilan keputusan, faktorfaktor yang dimaksud dalam penelitian ini adalah faktor minat, motivasi, cita-cita, keluarga, lingkungan, dan teman sebaya. Faktor-faktor tersebut di dapat dari kesimpulan teori yang dimukakan oleh beberapa ahli dalam teori pengambilan keputusan. Setelah dijelaskan teori pengambilan keputusan menurut tiga ahli yaitu Dalyono, Slameto, dan Djaali maka peneliti menyimpulkan bahwa faktor-faktor yang akan diteliti dalam penelitian ini ada dua yaitu faktor internal dan faktor eksternal. Faktor internal terdiri dari minat, motivasi, dan cita-cita, serta faktor eksternal terdiri dari keluarga, lingkungan, dan teman sebaya. Untuk mendapatkan hasil penelitian, maka didapatlah subjek untuk penelitian ini adalah mahasiswa program studi Pendidikan Olahraga Universitas Bina Darma angkatan tahun 2015sampai dengan angkatan tahun 2017 yang berjumlah 79 orang mahasiswa.

Dipilihnya mahasiswa tahun angkatan tersebut sebagai subjek penelitian dikarenakan pada angkatan tersebutlah mahasiswa masih menempuh perkuliahan dengan efektif sehingga akan memudahkan peneliti untuk melakukan penelitian disebabkan mahasiswa tersebut masih belajar di dalam ruang kuliah yang sama. Mahasiswa angkatan tahun 2014 tidak dijadikan subjek penelitian dikarenakan pada angkatan tersebut akan dijadikan peneliti sebagai respondes untuk uji validitas angket. Teknik pengumuplan data yang digunakan peneliti untuk mengetahui faktor-faktor yang mempengaruhi mahasiswa dalam memilih program studi Pendidikan Olahraga Universitas Bina Darma yaitu angket.Pada angket penelitian terdiri dari 6 indikator pernyataan yaitu minat, motivasi, cita-cita, keluarga, lingkungan, dan teman sebaya.Angket sebelum diuji validitas 
menggunakan responden mahasiswa angkatan tahun 2014 telah di periksa terleih dahulu oleh dosen validator yaitu Bapak Waspodo dan Ibu Dian Rianawati.

Pemberian angket terdiri dari 69 item pernyataan dengan item pernyataan tersebut untuk mewakili masing-masing faktor yang mempengaruhi memilih program studi. Adapun pembagian pernyataan untuk masingmasing faktor yaitu sebanyak 9 butir untuk pernyataan faktor minat, 13 butir untuk pernyataan faktor motivasi, 13 butir untuk pernyataan faktor cita-cita, 10 butir untuk pernyataan faktor keluarga, 13 butir untuk pernyataan faktor lingkungan, dan 11 butir untuk pernyataan faktor teman sebaya. Penentuan faktor apa yang lebih mempengaruhi mahasiswa dalam memilih program studi Pendidikan Olahraga Universitas Bina Darma pada angkatan tahun 2015 sampai dengan angkatan tahun 2017 yaitu dengan cara menskor masing-masing item pertanyaan, skor yang tertinggi pada kolom faktor merupakan faktor yang dominan dipilih oleh mahasiswa.

Mahasiswa yang memilih program studi Pendidikan Olahraga Universitas Bina Darma berdasarkan faktor minat pada saat melakukan kegiatan perkuliahan memiliki keyakinan untuk memulai perkuliahan dengan usaha, optimis pada tujuan menjalankan yang digeluti serta menyelesaikan sebuah permasalahan maupun tantangan yang dihadapi.Sehingga mahasiswa yang dipengaruhi oleh faktor minat memiliki nilai keyakinan, optimis dan ketidaktergantungan dalam mencapai tujuan yang telah ditetapkan.

\section{SIMPULAN}

Dari hasil analisis data yang telah dilakukan dalam penelitian ini dan pembahasan tentang faktor-faktor yang mempengaruhi mahasiswamemilih program studiPendidikan Olahraga Universitas Bina Darma maka dapat disimpulkan bahwa, dari 79 mahasiswa program studi Pendidikan Olahraga tahun angkatan 2015 sampai dengan tahun angkatan 2017 didapat bahwa 49 mahasiswa memilih faktor minat $(62,02 \%), 12$ mahasiswa memilih faktor motivasi $(15,19 \%)$, 10 mahasiswa memilih faktor cita-cita $(12,66 \%), 5$ mahasiswa memilih faktor keluarga (6,33\%), 1 mahasiswa memilih faktor lingkungan $(1,26 \%)$, dan 2 mahasiswa memilih faktor teman sebaya $(2,53 \%)$. Sehingga faktor yang paling dominan yang mempengaruhi mahasiswa dalam memilih program studi Pendidikan Olahraga Universitas Bina Darma adalah faktor minat.

\section{DAFTAR PUSTAKA}

Arikunto, S., 2013. Dasar-Dasar Evaluasi Pendidikan. Jakarta: Bumi Aksara.

Basir, D., \& Dwi Hasmidyani. 2015. Evaluasi Proses dan Hasil Belajar. Palembang: UNSRI PRESS.

Dalyono, M. 2007. Psikologi Pendidikan. Jakarta: Rineka Cipta.

Hapsari, Iriani Indri. 2016.Psikologi Perkembangan Anak. Jakarta: Indeks. 
Jamaris, Martini. 2013. Orientasi Baru dalam

Psikologi Pendidikan. Jakarta: Ghalia

Indonesia

Pemerintah Republik Indonesia. 2012.

Undang-Undang Republik Indonesia

nomor 12 tahun 2012 tentang

Pendidikan Tinggi Bab IV Pasal 58 ayat

1. Jakarta.

Sugiyono. 2016. Metode Penelitian

Pendidikan Pendekatan Kuantitatif,

Kualitatif, dan R\&D. Bandung:

Alfabeta

Sunarto \& Hartono, A. 2013. Perkembangan

Peserta Didik. Jakarta: Rineka Cipta.

Tjiptono, F. 2014. Pemasaran Jasa Prinsip,

Penerapan, Penelitian. Jakarta:

Gramedia Cawang. 